\title{
Lumbar synovial cyst calcification after facet joint steroid injection
}

\author{
Louis Boissière, ${ }^{1}$ Florent Valour, ${ }^{2}$ Julien Rigal, ${ }_{1}^{1}$ Christian Soderlund ${ }^{3}$
}

${ }^{1}$ Department of Orthopedic Spinal Surgery, Bordeaux Pellegrin Hospital, Bordeaux, France

${ }^{2}$ Department of Internal Medicine, French Polynesia Hospital Center, Pirae, French Polynesia

Department of Orthopedic Surgery, French Polynesia Hospital Center, Pirae, French Polynesia

Correspondence to Florent Valour,

florent.valour@chu-lyon.fr

\section{DESCRIPTION}

A 57-year-old man presented symptomatic L5 right sciatica since 2 years, becoming resistant to usual analgesics. Non-contrast CT scan of the lumbar spine disclosed an intraspinal synovial cyst with the same intensity as the intervertebral disc (figure 1A, arrow). A CT-scan-guided intra-articular steroid injection was performed (one injection of $3.75 \mathrm{mg}$ of cortivazol, equivalent to $62.5 \mathrm{mg}$ of prednisone; figure 1B), allowing a moderate improvement of the symptomatology after 1 month. However, the radiculopathy worsened after 6 months. A second lumbar spine CT scan revealed a cyst evolution, which had entirely calcified, leading to a major stenosis of the lateral recess (figure 1C,D, arrows). A surgical L4-L5 posterior decompression and fusion was proposed to the patient. At 1 year follow-up, a complete relief of radicular pain was obtained.

Synovial cyst is a differential diagnosis of disc herniation in a radicular pain evaluation. Facet joint sustained-release steroid injection, the main non-surgical treatment of vertebral synovial cysts, is known to be safe and viable, with a reported favourable outcome rate of $40 \%$ after 6 months. ${ }^{1}$ If a thin calcified rim of the cyst can occur, no modification is generally observed. ${ }^{2}$ This case presents an unusual complication of this frequent procedure, leading to a full calcification of the cyst 6 months after the injection, leaving no other possibility than surgery to release the nerve root compression. Moreover, if some authors propose to manage facet joint cysts by simple resection, ${ }^{3}$ the complete calcification of the cyst requires achieving a complete arthrectomy associated with lumbar spine fusion.

\section{Learning points}

Synovial cyst is a rare cause of radicular pain, and a differential diagnosis of herniated disc.

- Facet joint sustained-release steroid injection, the main non-surgical management of synovial cysts, can rarely lead to full cyst calcification, leaving no other possibility than a complete arthrectomy associated with lumbar spine fusion.
To cite: Boissière L, Valour F, Rigal J, et al. BMJ Case Reports Published online: [please include Day Month Year] doi:10.1136/ bcr-2012-008029

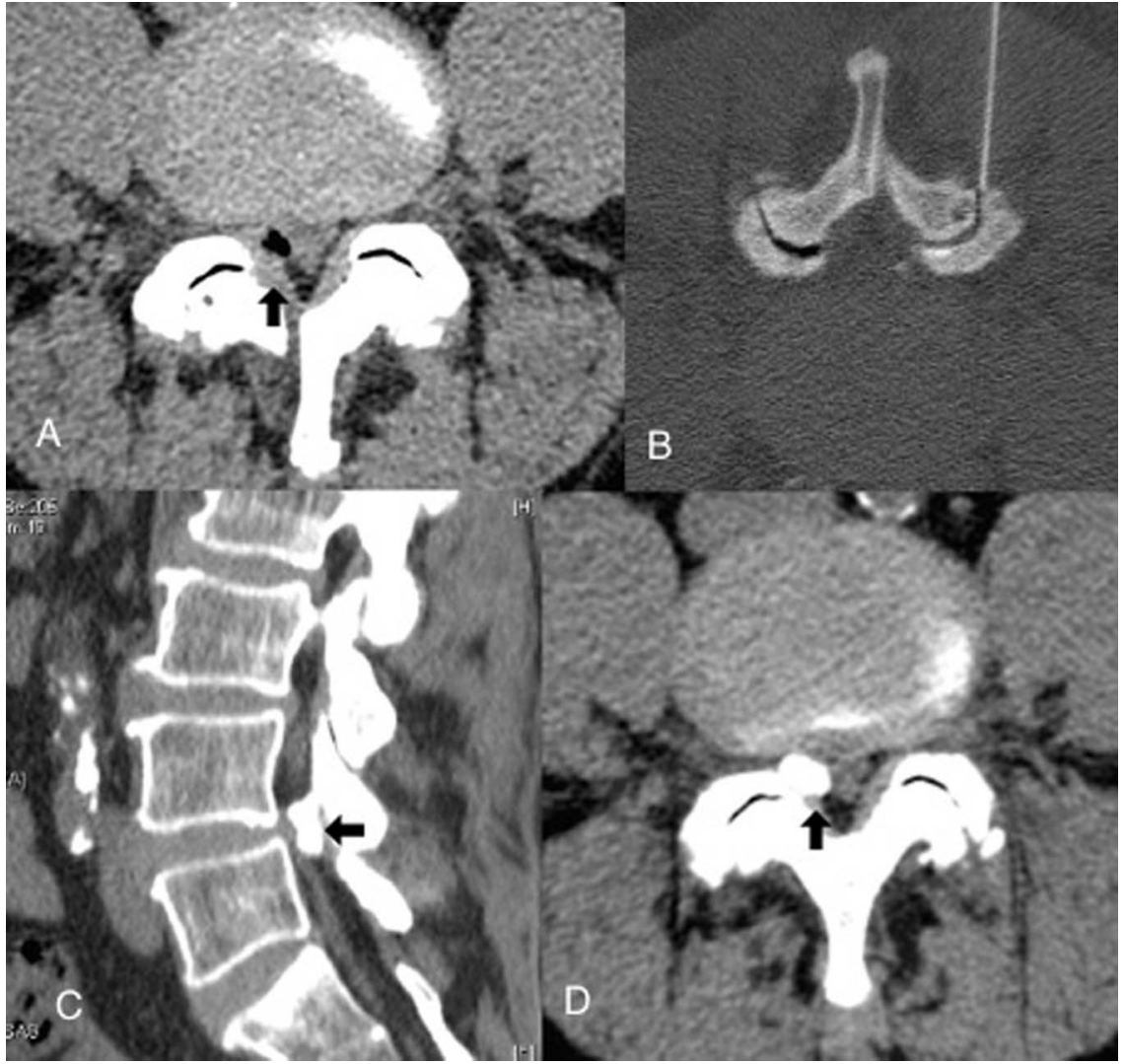

Figure 1 CT scan showing a L4-L5 right synovial cyst (A) managed by facet joint slow releasing steroid injection (B) complicated by a full cyst calcification 6 months later (C and D). 


\section{Competing interests None.}

Patient consent Obtained.

Provenance and peer review Not commissioned; externally peer reviewed.

\section{REFERENCES}

1 Parlier-Cuau C, Wybier M, Nizard R, et al. Symptomatic lumbar facet joint synovial cysts: clinical assessment of facet joint steroid injection after 1 and 6 months and long term follow-up in 30 patients. Radiology 1999;210:509-13.
2 Sauvage P, Grimault L, Salem D Ben, et al. Lumbar intraspinal synovial cysts: imaging and treatment by percutaneous injection. Report of thirteen cases. J Radiol 2000;81:33-8.

3 Landi A, Marotta N, Tarantino R, et al. Microsurgical excision without fusion as a safe option for resection of synovial cyst of the lumbar spine: long-term follow-up in monoinstitutional experience. Neurosurg Rev 2012;35:245-53.

Copyright 2013 BMJ Publishing Group. All rights reserved. For permission to reuse any of this content visit http://group.bmj.com/group/rights-licensing/permissions.

BMJ Case Report Fellows may re-use this article for personal use and teaching without any further permission.

Become a Fellow of BMJ Case Reports today and you can:

- Submit as many cases as you like

- Enjoy fast sympathetic peer review and rapid publication of accepted articles

- Access all the published articles

- Re-use any of the published material for personal use and teaching without further permission

For information on Institutional Fellowships contact consortiasales@bmjgroup.com

Visit casereports.bmj.com for more articles like this and to become a Fellow 